\title{
The Relationship between English Foreign Language Teachers' Willingness with Post-Method Pedagogy and Their Teaching Effectiveness
}

\author{
Hossein Khodabakhshzadeh \\ English Department, Torbat-e Heydarieh Branch, Islamic Azad University, Torbat-e \\ Heydarieh, Iran, hkhodabakhshzade@gmail.com
}

\section{Mahdi Arabi}

English Department, Torbat-e Heydarieh Branch, Islamic Azad University, Torbat-e Heydarieh, Iran, harabi2018@gmail.com

\section{Farideh Samadi}

English Department, Torbat-e Heydarieh Branch, Islamic Azad University, Torbat-e Heydarieh, Iran, samadi.farideh.86@gmail.com

$$
1
$$

The main purpose of this study is to investigate the relationship between English Foreign Language (EFL) teachers' willingness and conformity with post-method pedagogy and their teaching effectiveness. The participants comprised $134 \mathrm{EFL}$ teachers teaching and $487 \mathrm{EFL}$ learners studying at different language institutes in several cities of Iran. Their selection was based on random sampling and the participation was entirely voluntary. In this study, two instruments were used: post method questionnaire and Effective teaching questionnaire. Pearson's correlation coefficient and structural equation modeling (SEM) were run to analyze the causal relationships among the components. The results of Structural Equation Modeling demonstrated that effective teaching is positively and significantly predicted by all three subscales of post-method: teacher autonomy, teacher sense of social justice, and their sense of academic enthusiasm. Also, effective teaching is positively and significantly associated with total post method. Furthermore, effective teaching has the highest positive correlation with teacher enthusiasm, and the lowest positive correlation with teacher autonomy. Finally, these findings were discussed with reference to the context of Iran.

Keywords: post-method pedagogy, effective teaching, EFL teacher, EFL context, teacher autonomy

Citation: Khodabakhshzadeh, H., Arabi, M., \& Samadi, F. (2018). The Relationship between English Foreign Language Teachers' Willingness with Post-Method Pedagogy and Their Teaching Effectiveness. International Journal of Instruction, 11(2), 425-436. https://doi.org/10.12973/iji.2018.11229a 


\section{INTRODUCTION}

During last decades, English language teaching career has faced a drastic change of consideration and direction. One of the changes is the loss of methods (Allwright, 1991) from academic arguments and the increase of the post-method controversies. ELT teachers and practitioners came to this conclusion that no method is best for every situation (Kumaravadivelu, 1994). Then, in this situation, Kumaravadivelu (1994) proposed post-method pedagogy which was free from the method-based framework. "There was a never-ending enthusiasm for one method or another until Kumaravadivelu (2003) introduced the concept of the post-method era implying a move beyond methods" (as cited in Safari \& Rashidi, 2015, p.98). Kumaravadivelu (2006a) argues that "the post-method condition is a sustainable state of affairs that compels us to fundamentally restructure our view of language teaching and teacher education" ( $\mathrm{p}$. 170). Kumaravadivelu (2006b) adds that the aim of post-method is to train teachers to theorize their practice and to empower them and to give them autonomy. Teacher education traditionally "views teachers as passive recipients of transmitted knowledge rather than active participants in the construction of meaning ... does not take into account the thinking or decision-making of teachers" (Crandall, 2000, p. 35) while post method pedagogy views teachers as transformations of knowledge. In this situation "it is teachers who have to act as mediators between theory and practice, between the domain of disciplinary research and pedagogy" (Widdowson, 1990, p. 22). Also, teacher autonomy is one of the main factors of post-method that "it can be seen as defining the heart of post-method pedagogy" (Kumaravadivelu, 2001, p. 548). So, autonomous teachers have willingness and conformity with the post-method pedagogy. Finally, in this era teachers have a key role in their classes and their will and enthusiasm are considered as the main focus of education (Clarke, 1994). One of the main concerns of this pedagogy is teaching effectiveness. Teaching effectiveness has been defined differently by different people in different contexts based on their aims and constructs. Generally speaking, effective teaching means meeting educational goals and programs. Barry (2010) argued that "Effective teachers know who their students are. They know their students' learning styles, their strengths and their deficits as learners. They are masters of their subject matter...but more importantly, effective teachers are always focused on their students' learning" (p.8). Now, the question is whether the willingness and conformity of teachers with post-method condition makes them more effective.

Among some studies on postmethod pedagogy, Khany \& Darabi (2014) conducted a study in an Iranian ELT context focused on the reflection of principles-based and postmethod pedagogy in teachers' performance in the classroom. In addition, Tasnimi (2014) outlined the role of teachers in the postmethod era. Because of the possible relationship between teacher beliefs and classroom practices, these studies suggest a need to investigate the actual language teaching practitioners' perceptions of postmethod. Also, Post-method pedagogy is still a new concept, especially in Iran. So, few studies have been done in the field of post method pedagogy and especially its relation with teaching effectiveness. When the literature is reviewed, the absence of extensive literature on both postmethod pedagogy and teacher effectiveness suggests a clear need to examine postmethod pedagogy among EFL teachers in Iran and the extent 
which postmethod pedagogy contributes to teaching effectiveness. In that sense, interrelating teaching effectiveness and postmethod pedagogy framework may help to evaluate the relationship between these two important theoretical frameworks. Therefore, because of scarcity of researches in the area of post-method pedagogy, the aim of this study is to examine the relationship between EFL teachers' willingness and conformity with post-method pedagogy and their teaching effectiveness.

\section{Research Question}

Based on what was mentioned above, the present study aims to answer the following research question:

- Is there any significant relationship between Iranian EFL teachers' willingness and conformity with post-method pedagogy and their teaching effectiveness?

\section{REVIEW OF LITERATURE}

\section{Post-Method Pedagogy}

According to Rodgers (2000) the past century was the "age of methods" because language teaching methods convert to alternative methods (Richards \& Rodgers, 2003). Anthony (1963, as cited in Brown, 2002) called Method is "an overall plan" for demonstration of teaching materials on the basis of an elected way. Richards and Rodgers (1986) called method "as an umbrella" containing approach, design and procedure. Then as well, Prabhu (1990) defined method as classroom activities. Some researchers have stated several weaknesses of methods and have mentioned the reasons of inefficiency of them. Pennycook (1989) stated that methods symbolize concerned knowledge and they help the superior power system in community, resulting to "a deskilling of the role of teacher, and grater institutional control over classroom practice" (p. 610). Brown (2002) argues that methods are so prescriptive and alike to each other in some facets. As a result of these argumentations, Brown stated that the "concept of separate methods is no longer a central issue in language teaching practice" (p. 10).

Kumaravadivelu (2003) was the first person who introduced the concept of the "postmethod pedagogy". He (2006a) argues that the post-method condition is a tenable situation that constrains us to basically rebuild our perspective language teaching and teacher education. He (2006b) made further comment that the goal of post-method is to educate teachers to theorize their practice and to empower them and to give them autonomy. Furthermore, teacher autonomy is one of the main factors of post-method that can be viewed as characterizing the essence of post-method pedagogy (Kumaravadivelu, 2001, p. 548). Finally, in this era teachers have a key role in their classes and their will and enthusiasm are considered as the main focus of education (Clarke, 1994).

Kumaravadivelu (2006a) counted three principles as the components of post-method pedagogy as particularity, practicality, and possibility (as cited in Rashidi \& Khajavi, 2014):

1. Particularity: It is the chief constituent of post-method pedagogy referring to the role of context or situation. Kumaravadivelu (2006a) argues that we "must be sensitive to a 
particular group of teachers teaching a particular group of learners pursuing a particular set of goals within a particular institutional context embedded in a particular sociocultural milieu" (p. 171). In addition, Howatt \& Widdowson (2004) believe that teachers should not recognize local situation as limitation to be removed but situation to be meet. That is "a shift to localization".

2. Practicality: Kumaravadivelu (2001) argues that there should be conformity between theories and practices. In other words, theorizes of teachers should harmonize with practices in their classrooms. Theories and practices complement one another (Zakeri, 2014).

3. Possibility: Gholami, Bonyadi, and Mirzaei (2012) defined this principle as the degree that our interpreting of ourselves and our community are really influenced by the language we speak or study. This refers to the sociopolitical facet of English language teaching in post-method pedagogy.

Rashidi and Khajavi (2014) in their research tried to demonstrate post-method era and examine different aspects of this pedagogy. Also, they offered a number of strategies that help to fruitful implementation of post-method approach. In another study, Tasnimi (2014) first defined the notion of method and then the change from method to postmethod was examined. He second elaborated different approaches to post-method. Finally, he discussed about the role of teacher, teacher educator and prospective teacher. Regarding the researches done in the context of Iran, Safari and Rashidi (2015) carried out a semi structure interview and tried to reveal English teachers' limitations and obstacles in applying post-method as a new EFL pedagogy in Iran and found out different barriers in this regard. In another study, Khatib and Fathi (2014) investigated the controversial matter of post-method pedagogy by making known of it and proposing some strenuous problems that it creates for a post-method teacher in conduct. To sum up, the role of teacher is crucial in any post-method pedagogy. In this era, teachers are regarded as researchers, practitioners, theorizers of their practice and practitioners of their theories (Tasnimi, 2014).

\section{Teaching Effectiveness}

Teaching effectiveness has been defined differently by different people in different contexts based on their aims and constructs. According to James and Sammons (2013) effectiveness refers to the capability to promote achievement scores of students and to increase students' progress.

Barry (2010) mentioned that teaching effectiveness can be perceived by assessing what effective instructors know and carry out in their daily professional activities. Also, he (2010) argues that "these involve a deep understanding of subject matter, learning theory and student differences, planning, classroom instructional strategies, knowing individual students, and assessment of student understanding and proficiency with learning outcomes" (p.3-4). Marsh and Roche (1997) commented about the assessment of teaching effectiveness that "teaching effectiveness can be evaluated by current students, former students, the teacher himself or herself, colleagues, administrators, or trained observers (p. 1189). 
Regarding the researches done in this area, Kafi and Motallebzadeh (2015) examined the relationship between EFL teachers' effective teaching and the language learning motivation of Iranian EFL learners. They found a significant positive relationship between teachers' effective teaching and the L2 learners' language learning motivation. Brown (2009) in an attempt examined students' and teachers' perceptions of effective foreign language teaching by a 24-item questionnaire at the University of Arizona (As cited in Demiroz \& Yesilyurt, 2015). According to their result, the students are in favor of a grammar-based approach while their teachers preferred a more communicative classroom. Ashraf and Hosseinnia (2017) in their study examined the relationship between professional ethics and teacher effectiveness. Their results have shown that there is a significant relationship between those two variables. In another study, Hosseinnia (2017) also found the significant relationship between emotional intelligence and teaching effectiveness. So, various factors have positive relationship with teaching effectiveness. Also, it has been revealed that some factors have negative relationship with teaching effectiveness. Motallebzadeh, Ahmadi, and Hosseinnia (2017) in their study examined the relationship between EFL teachers' reflective practices and their teaching effectiveness. Their results indicated that there were positive and significant correlation between total reflective practices and total teaching effectiveness. In other words, higher scores on teachers' reflective practices correlated with high effective teaching. In addition, among five sub-factors of teachers' reflective practices, Affective reflection had the highest correlation and Critical reflection has the lowest correlation with total teaching effectiveness.

\section{METHOD}

\section{Participants}

Two groups participated in this study. The first group is 134 EFL teachers teaching at different language institutes in several cities of Iran. Their selection was based on random sampling and the participation was entirely voluntary. They were 50 females and 84 males whose age varied from 20 to $37(M=28.42, S D=3.21)$ with 1 to 15 years of teaching experience $(M=8.24, S D=2.79)$. The teachers had all majored in the various branches of English such as teaching, literature, and translation at B.A. or M.A. or PhD. This group of participants completed the post-method inventory. The other group is 487 EFL learners participated in this study from the above-mentioned institutes. Their ages ranged between 15 and $40(\mathrm{M}=24.35, \mathrm{SD}=4.24)$. All of them were intermediate and upper-intermediate learners of English. This group of participants assessed their teachers' effectiveness by Effective teaching questionnaire.

\section{Instruments}

In this study, two types of instruments were used. One instrument is post method questionnaire and the other is teaching effectiveness questionnaire.

\section{Post method questionnaire}

This questionnaire was developed and validated by Fat'hi, Ghaslani and Parsa (2015). This questionnaire included three factors of "Teacher sense of social justice, Teacher autonomy, and Teacher sense of academic enthusiasm" was developed based on the 
three components of practicality, particularity and possibility as proposed by Kumaravadivelu. It consisted of two parts. Part I is related to personal characteristics of respondents, such as gender, years of teaching experience and .... Part II has 29 items accompanied by a 6-point scale ranging from strongly disagree to strongly agree. The reliability calculated with Cronbach alpha was .85. Also, in order to examine the construct validity of the post-method questionnaire, two types of factor analysis, namely Exploratory Factor Analysis (EFA) and Confirmatory Factor Analysis (CFA) were used. To examine the reliability of the questionnaires Cronbach's Alpha was used. The reliability coefficient was .765 for Post Method Questionnaire, which shows the scale has an acceptable reliability.

\section{Effective teaching questionnaire}

Effective teaching questionnaire is designed by Kafi and Motallebzadeh (2015). It has 54 items based on a 5-point Likert scale varying from (1) "never" to (5) "always". It should be responded by the EFL students. The inventory included 4 subscales on effective teaching (Engagement, Delivery of Instruction, Behavior Management and Self-awareness of Personal Features) each of which includes up to 16 items. This inventory was validated by two experts in the ELT, also their reliability, using Cronbach's alpha, was estimated to be .87 .

\section{Procedure}

The data collection of this study took place in June and July 2017. This correlational study collected quantitative data through two questionnaires. The participants (teachers and learners) answered the questionnaires in the presence of the researcher. The questionnaire took about 30-40 minutes. There was no limitation of time in doing. After a brief explanation of the purpose of the research, the participants received the questionnaires. Moreover, the process of distribution of questionnaires was done by hand. We explained the purpose of completing the questionnaire and asked them not to write a name on them. They were required to provide demographic information such as, gender and years of experience only. After gathering the data, they were calculated in SPSS software and were analyzed by Structural equation modeling software.

\section{FINDINGS}

Descriptive statistics of effective teaching and different components of post method pedagogy questionnaire, in other words, teacher autonomy (TA), teacher sense of social justice (TSJ), and their sense of academic enthusiasm (TAE), are presented in Table 1.

Table 1

Descriptive statistics of effective teaching and different components of post method questionnaire

\begin{tabular}{llllll}
\hline & N & Min & Max & Mean & SD \\
\hline Effective Teaching & 487 & 79.00 & 211.00 & 149.58 & 15.24 \\
Teacher Autonomy & 134 & 7.00 & 28.00 & 24.19 & 3.11 \\
Teacher Sense of Social Justice & 134 & 15.00 & 56.00 & 47.30 & 6.24 \\
Teacher Sense of Enthusiasm & 134 & 21.00 & 63.00 & 55.12 & 7.48 \\
Total Post-Method Pedagogy & 134 & 35.00 & 162.00 & 109.04 & 13.29 \\
\hline
\end{tabular}


Table 2 summarizes the information obtained from Cronbach alpha analyses. As can be seen, the utilized questionnaires gained acceptable indices of Cronbach alpha as a whole as well as in their subscales.

Table 2

Results of Cronbach alpha indices after reliability analysis

\begin{tabular}{|c|c|c|}
\hline Scale & Subscales & Cronbach alpha \\
\hline \multirow{4}{*}{ Post Method } & Teacher Autonomy & .82 \\
\hline & Teacher Social Justice & .89 \\
\hline & Teacher Enthusiasm & .86 \\
\hline & Total & .91 \\
\hline \multirow{5}{*}{ Effective Teaching } & Engagement & .85 \\
\hline & Delivery of Instruction & .79 \\
\hline & Behavior Management & .81 \\
\hline & Self-awareness of Personal Features & .84 \\
\hline & Total & .88 \\
\hline
\end{tabular}

The alpha coefficient for Total Post Method (.91), and for total Effective Teaching (.88), suggest that the items have relatively acceptable internal consistency. Note that a reliability coefficient of .70 or higher is considered "acceptable" in most social and psychological science research situations (Evans, 1996).

To examine the research question, the proposed model was tested using the Amos 24 statistical package. To check the strengths of the causal relationships among the components, the standardized estimates were examined. As indicated in Figure 1, an estimate is displayed on each path.

A number of fit indices were examined to evaluate the model fit. As Table 3 shows the chi-square/df ratio (2.314), RMSEA (.062), GFI (.90), and CFI (.91), all the fit indices lie within the acceptable fit thresholds. Hence, it can be concluded that the proposed model had a perfect fit with the empirical data.

Table 3

Goodness of fit indices

\begin{tabular}{lllll}
\hline & X2/df & GFI & CFI & RMSEA \\
\hline Acceptable fit & $<3$ & $>.90$ & $>.90$ & $<.08$ \\
Model & 2.314 & .906 & .917 & .062 \\
\hline
\end{tabular}

Figure 1 represents the schematic relationships between effective teaching and subscales of post-method. The results demonstrated that effective teaching is positively and significantly predicted by all three subscales of post-method: teacher autonomy $(\beta=.17$, $p<.05)$, teacher sense of social justice $(\beta=.28, p<.01)$, and their sense of academic enthusiasm $(\beta=.35, p<.01)$. 


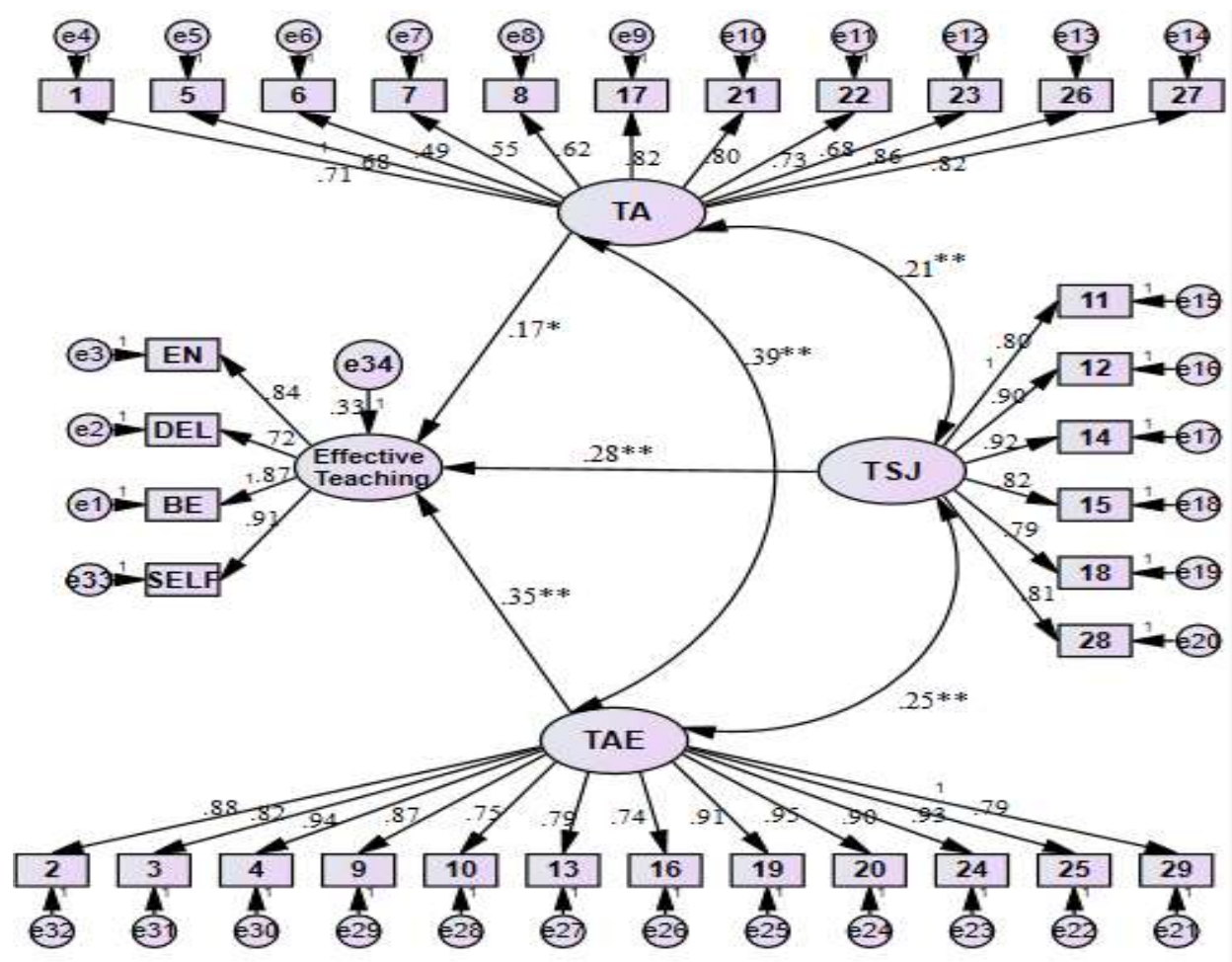

Figure 1

The schematic representation of the relationships between effective teaching and subscales of post-method

Note: $\mathrm{TA}=$ Teacher autonomy, $\mathrm{TSJ}=$ Teacher sense of social justice, $\mathrm{TAE}=\mathrm{Teacher}$ sense of academic enthusiasm, EN= Engagement, DEL= Delivery of Instruction, $\mathrm{BE}=$ Behavior Management, and SELF= Self-awareness of Personal Features.

The correlation coefficients between effective teaching and subscales of post-method are presented in Table 4.

Table 4

The Correlation Coefficients between effective teaching and subscales of post-method

\begin{tabular}{llllll}
\hline & 1 & 2 & 3 & 4 & 5 \\
\hline 1. Effective Teaching & 1.00 & & & & \\
2. teacher autonomy & $.227^{* *}$ & 1.00 & & & \\
3. Teacher Social Justice & $.408^{* *}$ & $.450^{* *}$ & 1.00 & & \\
4. Teacher Enthusiasm & $.495^{* *}$ & $.603^{* *}$ & $.411^{* *}$ & 1.00 & \\
5. Total post method & $.397^{* *}$ & $.771^{* *}$ & $.654^{* *}$ & $.702^{* *}$ & 1.00 \\
\hline
\end{tabular}

\footnotetext{
$* *$ correlation is significant at the level of 0.05
} 
As it can be seen, effective teaching is positively and significantly associated with total post method $(\mathrm{r}=.397, p<.05)$. Effective teaching has the highest positive correlation with teacher enthusiasm $(r=.495, p<.05)$, and the lowest positive correlation with teacher autonomy $(\mathrm{r}=.227, p<.05)$. The results will be discussed in the next section.

\section{DISCUSSION AND CONCLUSION}

One of the good strategies used by post-method teachers is teacher reflection. The results are consistent with Motallebzadeh et al. (2017) study who investigated the relationship between EFL teachers' reflective practices and their teaching effectiveness. Their results indicated that there were positive and significant correlation between total reflective practices and total teaching effectiveness. Also, one of the components of the post-method pedagogy is teacher autonomy. The findings of different studies (Berry, Daughtrey, \& Wieder, 2010; Hulpia, Devos, \& Van Keer, 2010) are in consistent with the finding of this study that the autonomous teachers are empowered teachers and may be more effective teachers and are influential in their students' achievement. Gurganiousn (2017) in his doctoral dissertation examined the relationship between teacher autonomy and students' achievement and he found a significant positive relationship between them. So, teachers who have more autonomy are more effective. Having autonomy allows the teachers to choose their own way of teaching based on their own teaching context. An autonomous teacher can develop his/her pedagogical practice in a way that is best for the students. Sense of having freedom and autonomy helps teachers to be more motivated in teaching (Pearson \& Moomaw, 2005).

The other component of post-method pedagogy is teacher sense of academic enthusiasm. An enthusiastic teacher is a motivated teacher. He/she has lots of energy for teaching and gives those energy and knowledge to students. The finding of this study revealed that the more academic enthusiast teacher is, the more effective he/she is. This finding corroborates previous researches (Ogochi 2014; Ololube, 2006) that found a significant relationship between teacher motivation and satisfaction and teacher effectiveness.

The final component is teacher sense of social justice. Based on the result, there is a relationship between teacher sense of social justice and teaching effectiveness. This finding confirms the finding of Kaur (2012) and Mills (2009) showing that teacher sense and disposition of social justice influence on teacher effectiveness. So, teacher effectiveness needs a socio-political knowledge and being aware of how students learn and progress.

The results demonstrated that effective teaching is positively and significantly predicted by all three subscales of post-method: teacher autonomy, teacher sense of social justice, and their sense of academic enthusiasm. Also, effective teaching is positively and significantly associated with total post method. Furthermore, effective teaching has the highest positive correlation with teacher enthusiasm, and the lowest positive correlation with teacher autonomy.

The findings of the study might offer some theoretical and practical implications as far as teacher education program is concerned. The findings might support the legitimacy 
and relevance of post-method pedagogy and principles. The principles of post method pedagogy make the teachers satisfied and more confident. So, the results of this study encourage the EFL teachers to leave using fixed and routinized methods and approach to the post method pedagogy in order to be more effective and satisfied. Obviously, readers must keep in mind that a study such as the present one has its own restrictions. This study employed questionnaires as the instruments for evaluating post method commitment that might not assess deeply the conformity of teachers with the principles of post-method pedagogy. This study can be replicated by means of a mix method approach to assess conformity of teachers with the principles of post-method pedagogy by other tools of data collection such as interviewing. Also, other researchers can do researches to find probable relationships between EFL teachers' conformity of teachers with the principles of post-method pedagogy with other variables such as teacher burn out.

\section{REFERENCES}

Allwright, R. L. (1991). The death of the method (Working Papers No. 10). Lancaster, England: The University of Lancaster, The Exploratory Practice Center.

Anthony, E. M. (1963). Approach, method, and technique. English Language Teaching, 17(2), 63-67.

Ashraf, H., \& Hosseinnia, M. (2017). EFL teachers' commitment to professional ethics and their teaching's effectiveness: A relationship study. Manuscript submitted for publication.

Barry, R. A. (2010). Teaching Effectiveness and Why It Matters. Marylhurst University and the Chalkboard Project.

Berry, B., Daughtrey, A., \& Wieder, A. (2010). A better system for schools: Developing, supporting and retaining effective teachers. New York: Center for Teaching Quality, Teachers Network.

Brown, H. D. (2000). Principles of Language Learning and Teaching. New York: Longman.

Brown, H. D. (2002). English Language Teaching in the post-Method era: Toward better diagnosis, treatment, and assessment. In J. C. Richards \& W. A. Renandya (Eds.), Methodology in language teaching: An anthology of current practice (pp.9-18). Cambridge: CUP.

Clarke, M. A. (1994). The Dysfunctions of the Theory/Practice Discourse. TESOL Quarterly, 28, 1, 10-27.

Crandall, J. A. (2000). Language teacher education. Annual Review of Applied Linguistics, 20, 34-55.

Demiroz, H., \& Yesilyurt, S. (2015). Effective foreign language teaching: Perceptions of prospective English language teachers. Universal Journal of Educational Research, 3 (11), 862-870. 
Evans, J. D. (1996). Straightforward statistics for the behavioral sciences. Pacific Grove, CA: Brooks/Cole Publishing.

Gholami, J., Bonyadi, A., \& Mirzaei, A. (2012). Postmodernism vs. Modernism in Iranian Non-Governmental English Language Institutes. Modern Journal of Language Teaching Methods, 128-143.

Gurganiousn, N. J. (2017). The relationship between teacher autonomy and middle school students' achievement in science. Unpublished doctoral dissertation, Walden University, Minneapolis, Washington, USA.

Hulpia, H., Devos, G., \& Van Keer, H. (2010). The influence of distributed leadership on teachers' organizational commitment: A multilevel approach. Journal of Educational Research, 103(1),40-52. doi:10.1080/00220670903231201

Hosseinnia, M. (2017, January, 20). EFL teachers' emotional intelligence and their teaching's effectiveness: A relationship study. A presented article in $37^{\text {th }}$ Annual Thailand TESOL International conference "ELT pathways to professional excellence".

Howatt, A. P. R., \& Widdowson, H. G. (2004). A history of English language teaching (2nd ed.). Oxford: OUP.

James, K., \& Sammons, P. (2013). Effective Teaching: A Review of Research and Evidence, Oxford University Press.

Kafi, Z., \& Motallebzadeh, KH. (2015). Effective teaching and language learning motivation: a study on the interconnection. Indonesian EFL Journal, 1(2), 135-143.

Kaur, B. (2012). Equity and social justice in teaching and teacher education. Teaching and Teacher Education, 28, 485-492.

Khany, R., \& Darabi, R. (2014). ELT in Iran: Reflection of the principles-based and post-method pedagogy in language teaching. Procedia - Social and Behavioral Sciences, 98(6), 908-916.

Khatib, M., \& Fathi, J. (2014). The investigation of the perspectives of Iranian EFL domain experts on post-method pedagogy: A Delphi technique. Journal of Teaching Language Skills, 33(3), 89-112.

Kumaravadivelu, B. (1994). The Post-Method Condition: (E)merging strategies for second/foreign language teaching. TESOL Quarterly, 28(1), 27-48.

Kumaravadivelu, B. (2001). Toward a Postmethod Pedagogy. TESOL Quarterly, 35(4), 537-560.

Kumaravadivelu, B. (2003). Critical language pedagogy: A post-method perspective on English language teaching. World Englishes, 22(4), 539-550.

Kumaravadivelu, B. (2006a). "TESOL methods: Changing tracks, challenging trends", TESOL Quarterly, 40(1), 59-81. 
Kumaravadivelu, B. (2006b). Understanding language teaching: From method to postmethod. New Jersey: Lawrence Erlbaum Associates.

Marsh, H. W., \& Roche, L. A. (1997). Making students' evaluations of teaching effectiveness effective. The American Psychological Association, Inc, 52(11), 1187-1197.

Mills, C. (2009). Making sense of pre-service teachers' dispositions towards social justice: can teacher education make a difference? Critical Issues in Education, 50(3), 277-288.

Motallebzadeh, KH., Ahmadi, F., \& Hosseinnia, M. (2017). The relationship between EFL teachers' reflective practices and their teaching effectiveness: A structural equation modeling approach. Manuscript accepted for publication in Cogent Psychology.

Ogochi, G. (2014). Job satisfaction and teacher effectiveness in selected secondary schools in Trans Mara West District, Kenya. Journal of Education and Practice, 5(37), 125-140.

Ololube, N. P. (2006). Teachers job satisfaction and motivation for school effectiveness: An assessment. Essays in Education, 1-18.

Pearson, L. C., \& Moomaw, W. (2005). The Relationship between teacher autonomy and stress, work satisfaction, empowerment, and professionalism. Educational Research Quarterly, 29(1), 37-53.

Pennycook, A. (1989). The concept of method, interested knowledge, and the politics of language teaching. TESOL Quarterly, 23 (4), 589-618.

Prabhu, N. S. (1990). There is no best method-why. TESOL Quarterly, 24 (2), 161-176.

Rashidi, N., \& Khajavi, Y. (2014). The Post Method Era: Opportunities and Challenges. Humanistic Language Teaching Magazine, 3. Retrieved April 16, 2016, from http://www.hltmag.co.uk/jun14/sart08.htm

Richards, J., \& Rodgers, T. S. (2003). Approaches and Methods in Language Teaching (2nded.). Cambridge: CUP.

Rodgers, T. S. (2000). Methodology in the new millennium. English Teaching Forum, $38(2), 2-13$

Safari, P., \& Rashidi, N. (2015). A Move towards Post-Method Pedagogy in the Iranian EFL Context: Panacea or More Pain? PASAA, 50, 95-124.

Tasnimi, M. (2014). The Role of Teacher in the Postmethod Era. An International Journal of Multi-Disciplinary Research. 1(3), 1-8.

Widdowson, H. G. (1990). Aspects of Language Teaching. Oxford: Oxford University Press.

Zakeri, E. (2014). Postmethod era: Amalgamation of methods, a real example. International Journal of Language Learning and Applied Linguistics World. 5(2), 523-529. 